\title{
The Effect of Super Set Weight Training Model and a High-Protein Diet on Body Fat Level Changes in Overweight and Obese Adult Men
}

\author{
Reshandi Nugraha*, Adang Suherman, Hamidie Ronald Daniel Ray, Amung Ma'mun \\ Faculty of Sport and Health Education \\ Universitas Pendidikan Indonesia \\ Bandung, Indonesia \\ *reshandi@upi.edu
}

\begin{abstract}
The purpose of this study was to determine the effect of super set weight training model and high protein diet on the changes in body fat levels for overweight and obese adult men. The method used in this study was true experimental design with the randomized subject control group pretest-posttest design. The subjects in this study were 30 overweight and obese adult male VIP Fitness Center members. Random sampling was used to determine 15 people to be included in the experimental group and 15 people to be included in the control group. The instrument used to measure the body fat percentage was Tanita. The data obtained were statistically analyzed by using the Paired Sample t-test and Independent Sample t-test analysis techniques with the significance $\alpha<0.05$ based on data analysis. Both groups obtained significance of 0.00 . Since the significant value was smaller than 0.05 , then $\mathrm{HO}$ was rejected. Therefore, at a $95 \%$ confidence level, it can be concluded that both groups experienced a decrease in body fat percentage, but the experimental group experienced a greater decrease in body fat percentage. Overweight and obese adult men who want to reduce their body fat percentage can apply weight training only. However, to get better results, they can apply the super set weight training model combined with a high protein diet.
\end{abstract}

Keywords: body fat levels, high-protein diet, overweight and obese adult men, super set, weight training

\section{INTRODUCTION}

The prevalence of overweight and obese is already high and continues to rise [1]. Not only in developed countries, the number of sufferers of overweight and obesity also continues to increase in developing countries [2,3]. Even since 1997, WHO has published an important document which states that obesity is a worldwide disease that poses a serious threat to public health [4]. Overweight and obese can substantially increase the risk of death and can cause various types of chronic diseases including; diabetes, hypertension, and cardiovascular disease [5]. A person is declared overweight if his body mass index is between $25 \leq 30 \mathrm{~kg} / \mathrm{m} 2$ [6]. While declared obese if the body mass index is $\geq 30 \mathrm{~kg} / \mathrm{m} 2$ [7]. The body is overweight and excess fat in the body, which is caused by a lack of physical activity and the habit of consuming food in excess calories [8]. Therefore serious efforts should be made for overweight and obese sufferers to avoid non-infectious diseases that can cause death.

Diet is the most common method for reducing fat levels in obese people [15]. Although the main cause of obesity is low levels of physical activity [16]. Several studies have shown that physical activity in obese adults without being followed by diet can reduce weight around (1 to $2 \mathrm{~kg}$ ) [9]. Whereas weight training without dieting in the elderly can improve BMI [13]. From these studies it can be concluded that there are only a few changes in weight loss and BMI, and no known percentage of reduced body fat. The development of technology nowadays there are already many instruments that can easily evaluate body composition and distribution of body fat $[11,17]$. So by using these instruments can determine the reduction in fat levels in the body of obese people due to the effect of partial exercise or exercise combined with diet.

Obesity is related to the occurrence of lifestyle-related diseases. An accurate diagnosis of obesity is important for health maintenance [18]. Physical activity alone is not a useful method for reducing obesity [5]. Weight training and diet can reduce simple but clinically significant body fat percentages [12]. The superset weight training model is currently widely used by personal trainers at the VIP Fitness Center, but it is not yet known whether the exercise model can reduce body fat percentage. High protein diet continues to be a popular dietary approach [23]. The results showed a diet high in protein could reduce fat mass greater [22,23]. So to reduce the percentage of body fat in obese people can be applied to super set weight training model combined with a diet high in protein. We hypothesize that the superset weight training model combined with a high-protein diet can influence the reduction in body fat levels in overweight and obese adult man. If this is true, it will add important insights for adult men who experience overweight and obesity to reduce the percentage of body fat to avoid non-infectious diseases that can cause death.

\section{Materials AND Method}

\section{A. Subjects}

The subjects in this study were VIP Fitness Center members, amounting to 30 overweight and obese adult men. 
The results of the paired sample t-test calculation in the Because in this study to determine the decrease in body fat levels, the subjects in this study were adult men members of the VIP Fitness Center who had body fat levels above $20 \%$. After obtaining as many as 30 adult men subjects with fat levels above $20 \%$, then random sampling was conducted to determine 15 people included in the experimental group and 15 people included in the control group.

\section{B. Exercise and Diet}

Each group was treated for 6 weeks. The experimental group received the super set model weight training 3 times a week, consisting of the first session of weight training for the lower body, the second session of weight training for the upper body, and the third session of weight training for total body. Superset weight training model applied in this study is to do two exercises alternately with opposing muscle targets, for example the first movement is bicep curl as many as 15 reps, after finishing followed by the second movement is triceps extension of 15 reps, then rest 1 minute and resumed the same movements each of 3 sets. While the control group was treated with weight training 3 times a week with an exercise program according to their individual needs. The experimental group received the treatment of a balanced nutritional diet for 6 weeks, consisting of 3 meals a day with the proportion of carbohydrate consumption as much as $30 \%$, protein as much as $40 \%$, and fat as much as $30 \%$. While the control group is free in determining its daily nutrition.

\section{Measurement of Body Fat Percentage}

The calculation of body fat percentage was done 2 times for each subject of research, first at pretest and second at posttest using Tanita BC-418MA. Pretest is done before the research subject receives treatment, while posttest is done after the research subject has finished receiving treatment for 6 weeks. The workings of the BC-418MA Tanita first manually input gender, age, height, and body type [10]. Then the subject in light clothing stands upright on 8 electrodes without using footwear or shoes, then wait for approximately 10 seconds the subject's body fat percentage will appear on the screen [11].

\section{Statistical Analysis}

Statistical techniques to determine the effect of each variable using the paired sample t-test. While statistical techniques to determine the effect is better by using the average difference test (Independent Sample t-test Posttest).

\section{RESULTS}

The results of the paired sample t-test calculation in the control group can be seen in table 1 with a significance value of $0.00<0.05$ then there is a significant effect of weight training on decreasing body fat percentage.

TABLE I. SUMMARY PAIRED SAMPLE T-TEST OF CONTROL GROUP

\begin{tabular}{|l|l|l|l|}
\hline \multirow{2}{*}{$\begin{array}{c}\text { Control Group Paired } \\
\text { Sample t-test }\end{array}$} & \multicolumn{2}{|c|}{ Paired Differences } & \multirow{2}{*}{$\begin{array}{c}\text { Significant } \\
\text { (2-tailed) }\end{array}$} \\
\cline { 2 - 3 } & Mean & Std. Deviation & \\
\hline $\begin{array}{l}\text { Pre-test body fat } \\
\text { percentage - Post-test } \\
\text { body fat percentage }\end{array}$ & 2.06333 & 0.24422 & 0.000 \\
\hline
\end{tabular}


compared to the control group which experienced a $2.06 \%$ decrease in body fat percentage. Whereas the statistical calculation of the experimental group had a larger t-count of 11.58, compared to the control group of 9.83. High protein diets given to the experimental group can increase lean body mass [21]. In addition, the results of the study for (4 months) in 48 overweight and obese women were asked to consume foods high in protein $(30 \%)$ vs normal protein $(18 \%)$, energy-limited diet (1700 kcal / day), resulting in a decrease in the percentage greater fat and body weight occurred in the group that consumed high protein [22].

\section{CONCLUSIONS}

Weight training only or super set weight training models combined with a high-protein diet can reduce body fat percentage in obese adult men. The super set weight training model group combined with a high protein diet is superior to the weight training group only in reducing body fat percentage. Overweight and obese adult men who want to reduce their body fat percentage can apply weight training only but to get better results can apply the super set weight training model combined with a high protein diet.

\section{REFERENCES}

[1] A.H. Mokdad, B.A. Bowman, E.S. Ford, F. Vinicor, J.S. Marks. and J.P. Koplan, "The continuing epidemics of obesity and diabetes in the United States," Jama, vol. 286(10), pp. 1195-1200, 2001.

[2] M.A. Mendez, C.A. Monteiro and B.M. Popkin, "Overweight Exceeds Underweight Among Women In Most Developing Countries," Am J Clin Nutr, vol. 81, pp. 714-721, 2005.

[3] Y. Nakata, K. Ohkawara, D.J. Lee, T. Okura, and K. Tanaka, "Effects of additional resistance training during diet-induced weight loss on bone mineral density in overweight premenopausal women," Journal of bone and mineral metabolism, vol. 26(2), pp. 172-177, 2008

[4] World Health Organization, "Obesity: preventing and managing the global epidemic: report of a WHO consultation on obesity, Geneva, 3-5 June 1997 (No. WHO/NUT/NCD/98.1)," Geneva: World Health Organization, 1998.

[5] R. Ross, D. Dagnone, P.J. Jones, H. Smith, A. Paddags, R. Hudson, and I. Janssen, "Reduction in obesity and related comorbid conditions after diet-induced weight loss or exercise-induced weight loss in men: a randomized, controlled trial," Annals of internal medicine, vol. 133(2), pp. 92-103, 2000.

[6] J.C.Y. Wu, L.M. Mui, C.M.Y. Cheung, Y. Chan, and J.J.Y. Sung, "Obesity is associated with increased transient lower esophageal sphincter relaxation,” Gastroenterology, vol. 132(3), pp. 883-889, 2007.

[7] E.J. Adams, L. Grummer-Strawn, and G. Chavez, "Food insecurity is associated with increased risk of obesity in California women," The Journal of nutrition, vol. 133(4), pp. 1070-1074, 2003.

[8] S. Lee, J.L. Kuk, L.E. Davidson, R. Hudson, K. Kilpatrick, T.E. Graham, and R. Ross, "Exercise without weight loss is an effective strategy for obesity reduction in obese individuals with and without Type 2 diabetes," Journal of Applied Physiology, vol. 99(3), pp. 12201225,2005 .
[9] National Institutes of Health, "Clinical guidelines for the identification, evaluation, and treatment of overweight and obesity in adults-the evidence report," Obes Res, vol. 6(2), pp. 51S-209s, 1998.

[10] U.G. Kyle, I. Bosaeus, A.D. De Lorenzo, P. Deurenberg, M. Elia, J.M. Gómez, B.L. Heitmann, L. Kent-Smith, J.C. Melchior, M. Pirlich, and H. Scharfetter, "Bioelectrical impedance analysis-part I: review of principles and methods," Clinical nutrition, vol. 23(5), pp. 1226-1243, 2004.

[11] A. Jiménez, W. Omaña, L. Flores, M.J. Coves, D. Bellido, V. Perea, and J. Vidal, "Prediction of whole-body and segmental body composition by bioelectrical impedance in morbidly obese subjects," Obesity surgery, vol. 22(4), pp. 587-593, 2012.

[12] R.J. Sigal, A.S. Alberga, G.S. Goldfield, D. Prud'homme, S. Hadjiyannakis, R. Gougeon, P. Phillips, H. Tulloch, J. Malcolm, S. Doucette, and G.A. Wells, "Effects of aerobic training, resistance training, or both on percentage body fat and cardiometabolic risk markers in obese adolescents: the healthy eating aerobic and resistance training in youth randomized clinical trial," Jama Pediatrics, vol. 168(11), pp. 1006-1014, 2014.

[13] N. Schott, B. Johnen, and B. Holfelder, "Effects of free weights and machine training on muscular strength in high-functioning older adults," Experimental gerontology, vol. 122, pp. 15-24, 2019.

[14] S. Lee, F. Bacha, T. Hannon, J.L. Kuk, C. Boesch, and S. Arslanian, "Effects of aerobic versus resistance exercise without caloric restriction on abdominal fat, intrahepatic lipid, and insulin sensitivity in obese adolescent boys: a randomized, controlled trial," Diabetes, vol. 61(11), pp. 2787-2795, 2012.

[15] D.F. Williamson, M.K. Serdula, R.F. Anda, A. Levy, and T. Byers, "Weight loss attempts in adults: goals, duration, and rate of weight loss," American journal of public health, vol. 82(9), pp. 1251-1257, 1992.

[16] L.O. Schulz, and D.A. Schoeller, "A compilation of total daily energy expenditures and body weights in healthy adults," The American journal of clinical nutrition, vol. 60(5), pp. 676-681, 1994.

[17] S.K. Das, "Body composition measurement in severe obesity," Current Opinion in Clinical Nutrition \& Metabolic Care, vol. 8(6), pp. 602-606, 2005 .

[18] S.K. Park, J.H. Park, Y.C. Kwon, H.S. Kim, M.S. Yoon, and H.T. Park, "The effect of combined aerobic and resistance exercise training on abdominal fat in obese middle-aged women," Journal of physiological anthropology and applied human science, vol. 22(3), pp. 129-135, 2003.

[19] B.F. Hurley, and S.M. Roth, "Strength training in the elderly," Sports Medicine, vol. 30(4), pp. 249-268, 2000.

[20] C. Delagardelle, P. Feiereisen, P. Autier, R. Shita, R. Krecke, and J. Beissel, "Strength/endurance training versus endurance training in congestive heart failure," Medicine \& Science in Sports \& Exercise, vol. 34(12), pp. 1868-1872, 2002.

[21] H.J. Leidy, N.S. Carnell, R.D. Mattes, and W.W. Campbell, "Higher protein intake preserves lean mass and satiety with weight loss in pre-obese and obese women," Obesity, vol. 15(2), pp. 421-429, 2007.

[22] D.K. Layman, E. Evans, J.I. Baum, J. Seyler, D.J. Erickson, and R.A. Boileau, "Dietary protein and exercise have additive effects on body composition during weight loss in adult women," The Journal of nutrition, vol. 135(8), pp. 1903-1910, 2005.

[23] J. Eisenstein, S.B. Roberts, G. Dallal, and E. Saltzman, "High-protein weight-loss diets: are they safe and do they work? A review of the experimental and epidemiologic data," Nutrition reviews, vol. 60(7), pp. 189-200, 2002. 